\title{
Assessing the influence of harvesting intensities on structural diversity of forests in south-west Germany
}

\author{
Felix Storch $^{1 *} \mathbb{D}$, Gerald Kändler ${ }^{2}$ and Jürgen Bauhus ${ }^{1}$
}

\begin{abstract}
Background: To increase ecosystem resilience and biodiversity, the maintenance and improvement of structural and compositional diversity of forests has become an important goal in forest management for many forest owners and jurisdictions. At the same time, future harvesting intensity (HI) may increase to meet the demand for woody biomass by an increasing bioeconomy sector. Yet, the influence of $\mathrm{HI}$ on forest structural diversity is largely unknown. Here, we address this issue by analyzing the relationship between $\mathrm{HI}$ and structural diversity based on large-scale national forest inventory (NFI) data, where the latter is quantified using a previously developed Forest Structure Index and $\mathrm{HI}$ is expressed as wood volume removal during the period 2002-2012 for the same inventory plots.
\end{abstract}

Results: Our results show a surprisingly small impact of harvesting intensity on changes in structural diversity for most of the analysed types of forests. Only intense harvesting (> 80\%-90\% of initial growing stock) led to a significant reduction in structural diversity. At low to moderate $\mathrm{HI}$ most aspects of structural diversity were positively influenced. Only the quadratic mean $\mathrm{DBH}$ and the volume of large trees $(\geq 40 \mathrm{~cm} \mathrm{DBH})$ were substantially negatively influenced at $\mathrm{HI}>60 \%$ and $70 \%$ of initial growing stock, respectively.

Conclusions: In several forest types, HI could be increased without a reduction in overall structural diversity. Hence, structural diversity in these selectively managed forests appears to be a very resistant forest property in relation to $\mathrm{HI}$. Other indicators at stand and landscape scale may be needed to adjust levels of $\mathrm{HI}$ that are suited to maintain forest biodiversity.

Keywords: Large-scale inventory, Structural diversity index, Harvesting intensity, Changes in structural diversity

\section{Background}

A major challenge for modern forestry is the integration of wood production with other important values such as the conservation of biodiversity and ecosystem functioning (e.g. McDermott et al. 2010). Forest management changes the structure and composition of forests (e.g. Lindenmayer et al. 2000; Parrotta et al. 2002; Kuuluvainen 2009) and there is a general concern that forest biodiversity and ecosystem functioning are negatively impacted by increasing harvesting intensity (Raison et al. 2001; Bauhus et al. 2017a; Urli et al. 2017). It has been shown that the difference in key structural elements and composition between managed and natural forests

\footnotetext{
* Correspondence: felix.storch@waldbau.uni-freiburg.de

${ }^{1}$ Chair of Silviculture, University of Freiburg, D-79085 Freiburg, Germany

Full list of author information is available at the end of the article
}

(including naturally disturbed forests) increases with increasing harvesting intensity (e.g. Parrotta et al. 2002; de Avila et al. 2015; Urli et al. 2017). Yet, in many studies on the impact of forest management, the intensity of harvesting is actually not considered but comparisons are being made between unharvested or reserved and (recently) harvested forests (e.g. Gilliam 2002; Okland et al. 2003; Paillet et al. 2010). However, this approach has one important limitation. While the status of unharvested forest reserves can be reasonably well described and defined, harvested forests can cover a wide range of harvesting intensities, ranging from clearfelling to single tree selection. Hence, these simple comparisons between unharvested and harvested forests provide little information on the influence of harvesting intensity on forest structure and biodiversity (Fig. 1). 


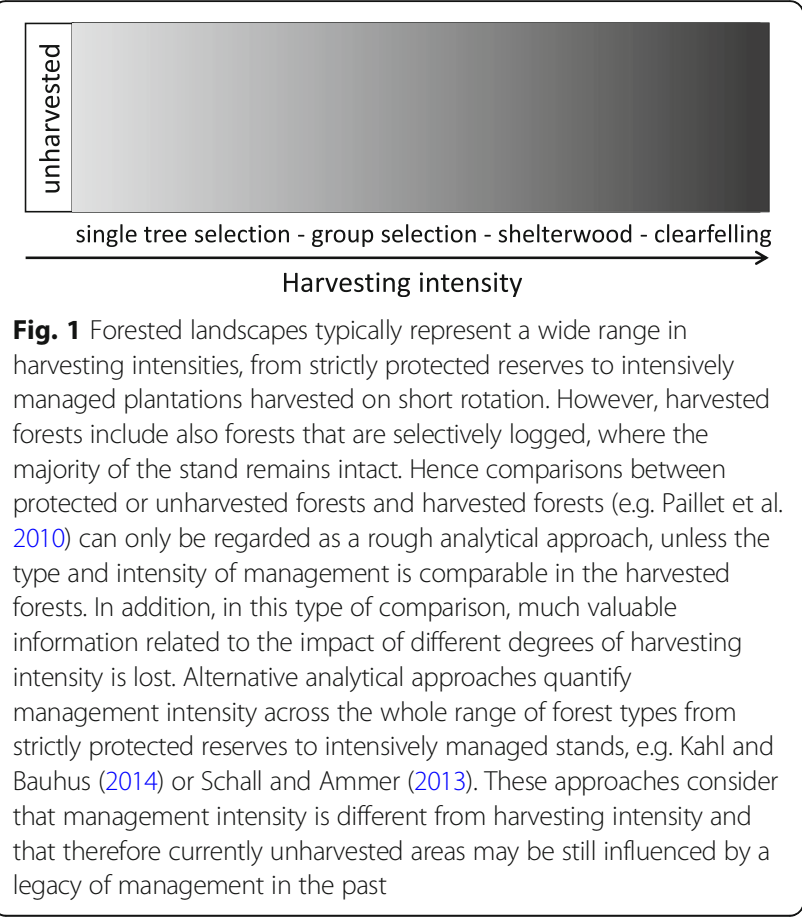

While there have been some studies that explicitly considered the influence of harvesting intensity or forest use intensity as a continuous variable, these typically focused on selected aspects of forest biodiversity such structural variables, tree diversity, forest understorey or particular taxonomic groups or were spatially restricted to small areas or regions (e.g. Fredericksen et al. 1999; Parrotta et al. 2002; González-Alday et al. 2008; Sullivan et al. 2008; Michel and Winter 2009; de Avila et al. 2015). Depending on the respective focus of these studies, impacts of harvesting intensity ranged from positive (e.g. for the diversity of forest understorey plant communities or tree species richness (Kern et al. 2006)) to negative (e.g. volume or dimension of downed deadwood and species depending on large dimensioned trees and dead wood (e.g. Müller et al. 2008; Gossner et al. 2013). The lack of broad-scale assessments of the relationship between harvesting intensity and biodiversity or biodiversity surrogates limits the generalization of these findings for larger areas (Gilliam 2002; Roberts and Zhu 2002; Vandekerkhove et al. 2016).

Management of semi-natural forests, in particular on public land, increasingly aims at maintaining or increasing compositional and structural diversity for a number of reasons (e.g. Franklin et al. 2002; Puettmann et al. 2015). Structurally and compositionally diverse forests may have a higher ecological stability than monocultures or one-layered stands in relation to biotic and abiotic stress and disturbances (Neuner et al. 2015; Thurm et al. 2016; Penone et al. 2019). According to the habitat heterogeneity hypothesis, the provision of many different niches and structural elements in diverse forests is assumed to support also a higher species richness (Simpson 1949; Tews et al. 2004; Jung et al. 2012). At the stand scale, this can be achieved, for example, by implementing management strategies such as 'retention forestry', where the intentional protection and development of forest structural elements across harvesting cycles can maintain habitats and organisms (Abrahamsson and Lindbladh 2006; Bauhus et al. 2009; Gustafsson et al. 2012). At the landscape scale, higher species richness may be achieved with increased beta-diversity through increasing variation among patches owing to differences in management or successional status (e.g. Hilmers et al. 2018; Schall et al. 2018a).

One of the major challenges in the assessment of forest harvesting intensity on biodiversity is that it is not possible to monitor biodiversity in all forests directly. Presence or diversity of species from different taxonomic groups can commonly be sampled only in case studies and for small areas (e.g. Laiolo 2002; Glaser 2006), which likely provides an incomplete and potentially unrepresentative picture. Therefore, the presence and the expression of different structural elements of forests have been suggested as surrogates for information about the abundance and richness of forest-dwelling species (e.g. McElhinny et al. 2006a; Jung et al. 2012). By analysing changes in structural diversity of forests, possible changes in communities of forest-dwelling species may be assessed too. Here we aim at assessing impacts on forest harvesting intensity based on large-scale forest inventory data. National forest inventory (NFI) data of Baden-Württemberg were used to include all different types of forests and an inventory period of 10 years to analyse these impacts in a comprehensive and representative way across the whole forest area and for a broad range of harvesting intensities from unharvested forest stands to clear-fellings.

Previous studies like those of Kahl and Bauhus (2014) or Schall and Ammer (2013) developed approaches to quantify forest management intensity along a continuum of human interference. For example, the index of forest management intensity (FORMI) developed by Kahl and Bauhus (2014) includes three criteria, the proportion of the total tree volume that has recently been harvested, the proportion of cultivated tree species that are not part of the natural forest community, and the proportion of the total dead wood volume that has originated from management activities. In other approaches that used a set of variables to describe management intensity by the level of naturalness (Bartha 2004; Winter et al. 2010), it is difficult to distinguish between independent and dependent variables. These types of approaches have been typically applied to relatively small areas, where detailed information about the necessary variables could be 
collected. If the influence of harvesting intensity on forest biodiversity is to be assessed on a large scale, it may be determined more directly on the basis of inventory data.

Here, we used harvesting intensity calculated on the basis of NFI data as the main predictor variable to analyse changes in structural diversity of forests over large areas. Based on data of the German National Forest Inventory for the state of Baden-Württemberg (SWGermany, $\mathrm{NFI}_{2002}$ and $\mathrm{NFI}_{2012}$ ), an index has been developed to assess the level of structural diversity of forests comprehensively (Storch et al. 2018). This index ('FSI' Forest Structure Index) combines many forest attributes that cover important habitat components of forest dwelling species; see 2.2. Results showed an increase of structural diversity (FSI-score) for most of the analysed types of forests in Baden-Württemberg (Storch et al. 2018).

We employed this index for our analysis because a) it describes structural diversity of forests in an objective manner b) it can be applied to large forest areas and to the whole range for forest types and site conditions and c) it can be directly related to harvesting intensity that is quantified for the same set of inventory plots. Thus, the influence of harvesting intensity on changes of structural diversity in different forest types can be assessed for the period between the two national inventories from 2002 and $2012\left(\mathrm{NFI}_{2002}-\mathrm{NFI}_{2012}\right)$.

Our hypothesis was that increasing harvesting intensity leads to a decrease in structural diversity of forests (e.g. Parrotta et al. 2002; Hartsough 2003; Cazzolla Gatti et al. 2015; Urli et al. 2017). However, no hypothesis was formulated regarding the shape of this relationship, i.e. whether the decrease followed a linear or non-linear function or at which harvesting intensity structural diversity of forests starts to decrease.

\section{Material \& methods \\ Data basis}

This study was based on 12,918 NFI plots in the state of Baden-Württemberg, Germany, covering approximately 1371 million ha (hectares) of forest area and including a broad range of different types of forests, management intensities, stand development phases and structural diversities. These plots were marked as 'forest' in $\mathrm{NFI}_{2002}$ and $\mathrm{NFI}_{2012}$ and were accessible at both inventories. An additional criterion for selection of NFI plots for our analysis was the presence of merchantable trees with a diameter at breast height (DBH) larger than $7 \mathrm{~cm}$ at $\mathrm{NFI}_{2002}$. The selected plots were distributed over the whole state of Baden-Württemberg and included 97.7\% of all sampled plots in $\mathrm{NFI}_{2002}$ (Storch et al. 2018). Further information about the inventory (systematic grid, sampling design and background of this inventory) can be found at BMEL (2013) (https://www.bundeswaldinventur.de).

\section{Structural diversity index (FSI)}

Based on data of $\mathrm{NFI}_{2002}$ and $\mathrm{NFI}_{2012}$ for the state of Baden-Württemberg, an index to assess the level of structural diversity of forests was developed (Storch et al. 2018) following the approach described by McElhinny et al. (2006b) and modifications suggested by Sabatini et al. (2015). Eleven variables, each representing different aspects of structural diversity, were applied to calculate the FSI in a simple additive way, without weightings of individual variables (Storch et al. 2018). These variables representing important habitat components, comprising the presence of standing and downed deadwood, different decay classes, the occurrence of large living trees, species richness of trees in the stand and the regeneration layer, quadratic mean diameter at breast height $(\mathrm{DBH})$, standard deviation of $\mathrm{DBH}$ and stand height, as well as the diversity of bark types and flowering trees. Each variable is scaled in relation to the minimal and maximal value that can be assumed for this aspect of structural diversity to yield values between 0 and 1 . This index, as the sum of the values of structural variables, was calculated at the plot-level and subsequently aggregated to forest types to obtain reliable estimates of structural diversity and its change between forest inventories. Index-values range between 0 and 1 , where 0 implies 'lowest level of structural diversity' and 1 'highest level of structural diversity'. Further information about the development of this index can be found in Storch et al. (2018).

\section{Calculation of harvesting intensities and relation to changes in structural diversity}

Based on the same data-set of subsequent national forest inventories $\left(\mathrm{NFI}_{2002}\right.$ and $\left.\mathrm{NFI}_{2012}\right)$, harvesting intensity (HI) was calculated for each inventory plot. In the NFI, the trees removed during the previous inventory period are identified from stumps and recorded for each plot. Since there is no precise information on the date of harvest, the volume of harvested trees is based on the assumption that trees are removed at the middle of the inventory period and their volume increment until this point in time is modelled. We decided to represent HI as percentage of the standing timber volume $\left(\mathrm{m}^{3} \cdot \mathrm{ha}^{-1}\right)$ at the time of the $\mathrm{NFI}_{2002}$. In this way, harvesting intensity is related to actual timber stocks and the actual intensity is described more accurately than by just volume per ha of harvested timber, which provides no information on relative changes to the growing stocks. Harvesting intensity was calculated for the inventory period between $\mathrm{NFI}_{2002}$ and $\mathrm{NFI}_{2012}$. For this period, a mean value of annual harvesting intensity (harvested 
timber volume divided by the duration of the inventory period (10 years)) was determined because no information about actual time of harvesting was available. These values were calculated on the basis of 12.918 forest plots, which were used to develop the FSI and its changes over a period of 10 years. This number of sampling plots is smaller than the total number of NFI plots in the state and hence the results may differ slightly from official NFI-analysis for Baden-Württemberg. Changes in the structural diversity of forests (FSI-changes) were also expressed as percentage of the FSI-values in 2002 at the beginning of the inventory.

To analyse influences of harvesting intensities on changes in structural diversity of forests, different models were calculated and compared to each other. For statistical analysis, the statistic-software ' $\mathrm{R}$ ' (Version 3.1.2) and package $m g c v$ for Generalized Additive Models were used (Wood 2006), as these models can be used in a flexible way, including different numbers and functions for the applied predictor variables. Additionally, the packages randomForest and lmer were used to calculate and compare different types of models to identify the model that describes best the relation between harvesting intensity and changes in structural diversity (Table 1). Plot-level HI data were aggregated to harvesting classes (10\%-intervals referred to standing timber volume of $\mathrm{NFI}_{2002}$ ), as the calculation of FSI and $\mathrm{HI}$ at the plotlevel includes a certain variability, caused by the sampling method for trees with a $\mathrm{DBH} \geq 7 \mathrm{~cm}$ which is based on the 'angle count method' - 'probability proportional to size'. This method is characterized by unequal probabilities for trees to be included in the sample in successive inventories as well as small sample areas for trees of small dimension (see also Bitterlich 1952; Motz et al. 2010; Storch et al. 2018). This variability can be reduced by aggregation of single plots into strata, here harvesting classes, containing at least 15 sampling plots. Therefore, results on the interactions of harvesting intensity and changes in structural diversity (FSI) were expressed for classes of HI, using 10\%-intervals, and not for individual plots.

\section{Results}

Mean harvesting intensity for the inventory period 2002-2012 varied surprisingly little for the different forest types analysed and was between $30 \%$ and $40 \%$ of the standing timber volume of $\mathrm{NFI}_{2002}$ (see also supplementary material). For that particular period, mean FSIscores increased in all analysed types of forests, except for young stand development phases (Storch et al. 2018).

Surprisingly, structural diversity increased for the entire population of NFI plots for a wide range of harvesting intensities (Fig. 2). A decrease in structural diversity was observed only for harvesting intensities greater than 90\% (similar graphs for different types of forests are provided in the Additional file 1). When compared to the average harvesting intensity of this inventory period, which was about $30 \%$, considerably more woody biomass could theoretically be harvested without a reduction in structural diversity. To understand the underlying patterns for the response of the FSI to harvesting intensity, the response of all individual variables of forest structure contributing to the FSI were analysed in relation to the gradient in harvesting intensity (Figs. 3 and 4 and Additional files 2 and 3).

As was the case for the full index, the influence of harvesting intensity on most individual variables used in the FSI was quite small for the entire inventoried forest area of Baden-Württemberg, as well as for the different types of forests (Fig. 3 and Additional files 2 and 3). A reduction in the score of some structural variables like 'DBHq' or 'Vol40' was found only at harvesting intensities higher than $60 \%$. Hence, the small influence of HI on structural diversity can be attributed to small changes in the individual variables and not to contrasting responses of different variables that outweigh each other. For forest inventory plots with no recorded harvest in the latest inventory period (4411 plots out of 12,918 sampled plots),

Table 1 List of models tested to explain the relationship between harvesting intensity and changes in structural diversity (FSIchange)

\begin{tabular}{|c|c|c|c|}
\hline Acronym & Model & Package & Explanation \\
\hline loess & loess & stats & $\begin{array}{l}\text { in addition to simply smoothing a curve, the R loess function can be used to impute missing } \\
\text { data points }\end{array}$ \\
\hline Im & linear model & stats & Im is used to fit linear models \\
\hline $\mathrm{glm}$ & $\begin{array}{l}\text { generalized linear } \\
\text { model }\end{array}$ & stats & $\begin{array}{l}\text { produces a generalized linear model for the relationship between } \mathrm{HI} \text { and change in structural } \\
\text { diversity (FSI) }\end{array}$ \\
\hline gam & $\begin{array}{l}\text { generalized additive } \\
\text { model }\end{array}$ & mgcv & $\begin{array}{l}\text { produces a generalized additive model for the relationship between } \mathrm{HI} \text { and change in } \\
\text { structural diversity (FSI) }\end{array}$ \\
\hline RF & randomForest & randomForest & $\begin{array}{l}\text { implements Breiman's random forest algorithm for classification and regression } \\
\text { (for harvesting classes) }\end{array}$ \\
\hline $\mathrm{HC}$ & harvesting classes & $\begin{array}{l}\text { No package } \\
\text { needed }\end{array}$ & $\begin{array}{l}\text { Harvesting classes for } 10 \% \text {-intervals, referred to the standing volume at } \mathrm{NFI}_{2002} \text { to generate } \\
\text { boxplots }\end{array}$ \\
\hline
\end{tabular}




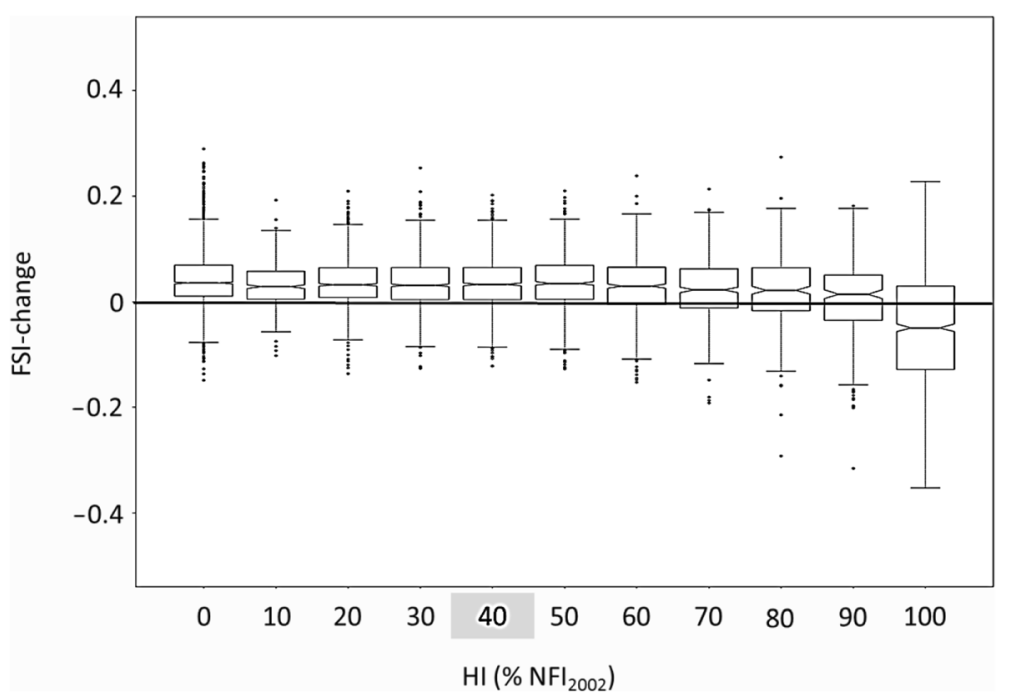

Fig. 2 Boxplots for changes in the Forest Structure Index in relation to harvesting intensity (in \% of standing timber volume per ha of NFI 2002 , depicted in 10\%-intervals). The grey square on the $x$-axis indicates average harvesting intensity for the entire forest area of Baden-Württemberg for the 10-year period between $\mathrm{NFI}_{2002}$ and $\mathrm{NFI}_{2012}$ (30.8\%); black horizontal line indicates no change in the FSI

changes in individual variables over the period of 10 years tended to be positive or neutral, but were quite variable. As shown in Fig. 4, relatively small changes were found for structural variables such as 'number of decay classes' and 'mean diameter of downed deadwood', indicating a limited dynamic in these aspects of structure; e.g. changes in decay classes need several years to decades to occur. Other variables like 'volume $\mathrm{ha}^{-1}$ of large living trees with a $\mathrm{DHB} \geq 40 \mathrm{~cm}$ ' showed relatively strong changes, indicating that these variables might change relatively fast or at least within a period of 10 years (e.g. after storm or drought). Changes in all individual variables used in the FSI for different forest types can be found in Additional file 3.

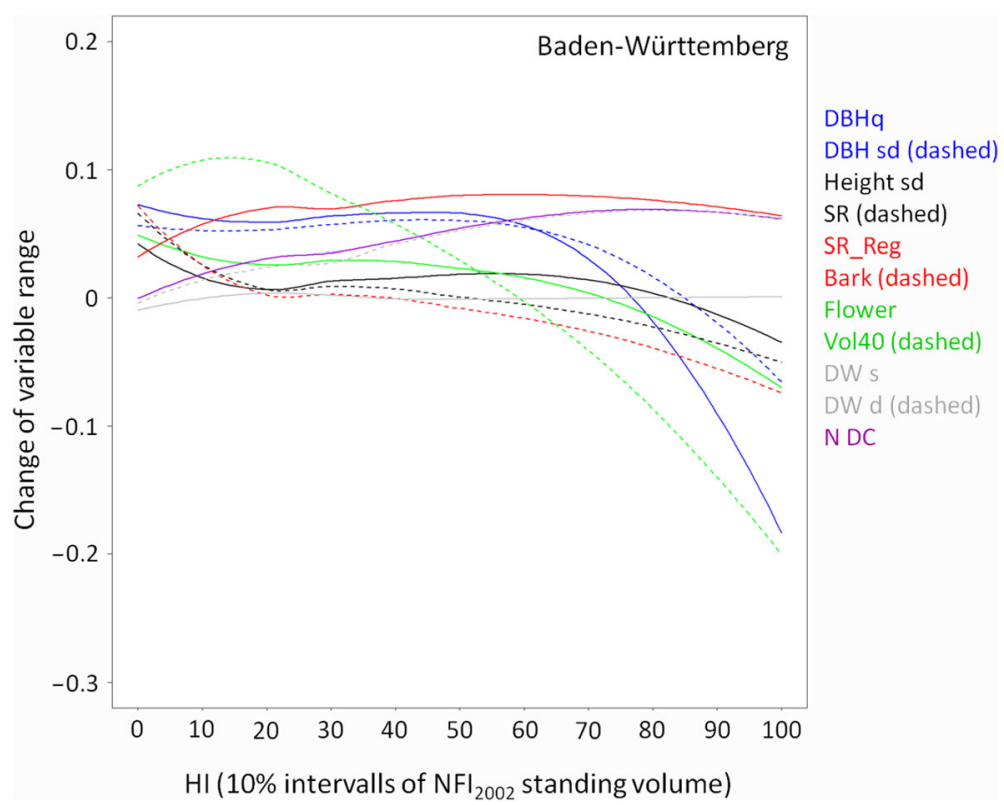

Fig. 3 Changes in ranges of individual variables of forest structure with harvesting intensity for national forest inventory plots from BadenWürttemberg; DBHq: quadratic mean diameter at breast height, DBH sd: standard deviation of diameter at breast height, Height sd: standard deviation of stand height, SR: species richness, SR Reg: species richness in regeneration layer, Bark: diversity of bark types, Flower: diversity of flowering trees, Vol40: occurrence of large living trees with a DBH $\geq 40 \mathrm{~cm}$, DW s: mean DBH of standing deadwood, DW d: mean diameter of downed deadwood and N DC: number of decay classes 


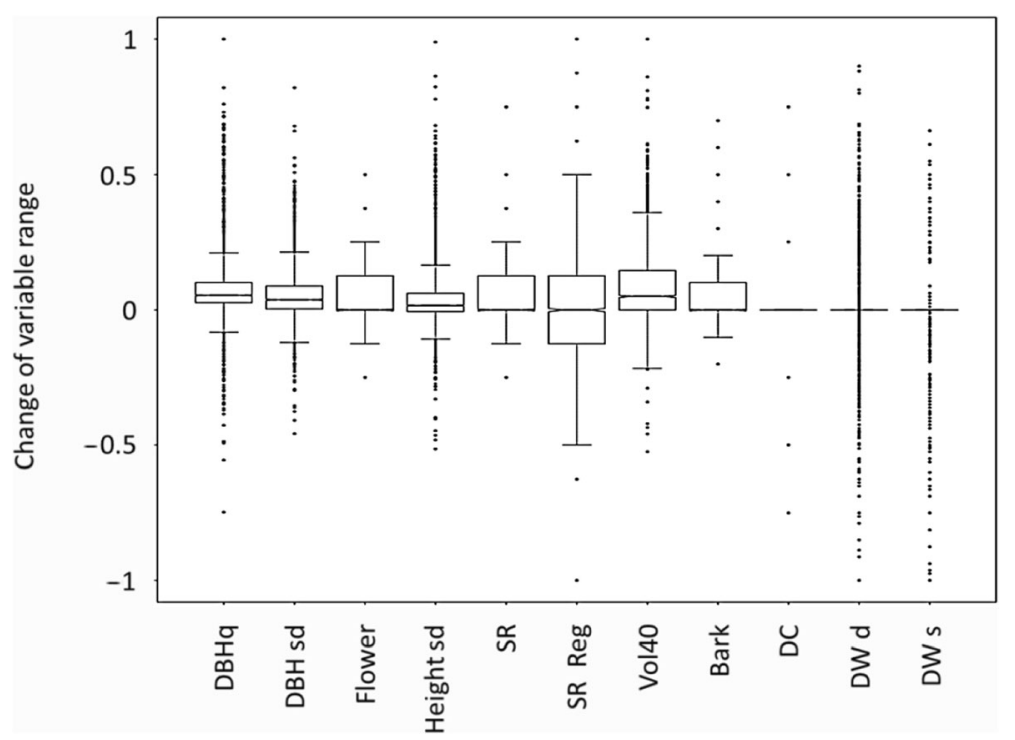

Fig. 4 Relative changes in values for individual variables of forest structure for plots with no harvesting activity $(H I=0)$ over the most recent inventory period (2002-2012) for Baden-Württemberg; DBHq: quadratic mean diameter at breast height, DBH sd: standard deviation of diameter at breast height, Height sd: standard deviation of stand height, SR: species richness, SR Reg: species richness in regeneration layer, Bark: diversity of bark types, Flower: diversity of flowering trees, Vol40: occurrence of large living trees with a DBH $\geq 40 \mathrm{~cm}$, DW s: mean DBH of standing deadwood, DW d: mean diameter of downed deadwood and N DC: number of decay classes

The influence of $\mathrm{HI}$ on structural diversity differs with stand development phases, as can be seen for the comparison between the first (mean $\mathrm{DBH} \leq 20 \mathrm{~cm}$ ) and second stand development phase (mean DBH between 20 and $50 \mathrm{~cm}$ ) (Fig. 5). In young stands, structural diversity responds considerably more sensitive and negative to harvesting intensity than in middle-aged stands, mainly caused by decreasing values for the variables 'quadratic mean diameter at breast height' and 'volume of trees with a $\mathrm{DBH} \geq 40 \mathrm{~cm}$ '.
Except for young stands (SDP1 - mean DBH $<30$ $\mathrm{cm})$, HI could be theoretically increased without a loss in structural diversity. In addition, structural diversity in conifer-dominated stands seems to be less influenced by $\mathrm{HI}$ than in broadleaf-dominated forest stands. For coniferous stands, especially spruce-dominated stands in the second stand development phase (SDP2 - mean DBH between 30 and $50 \mathrm{~cm}$ ), HI may be doubled before a loss in structural diversity occurs.

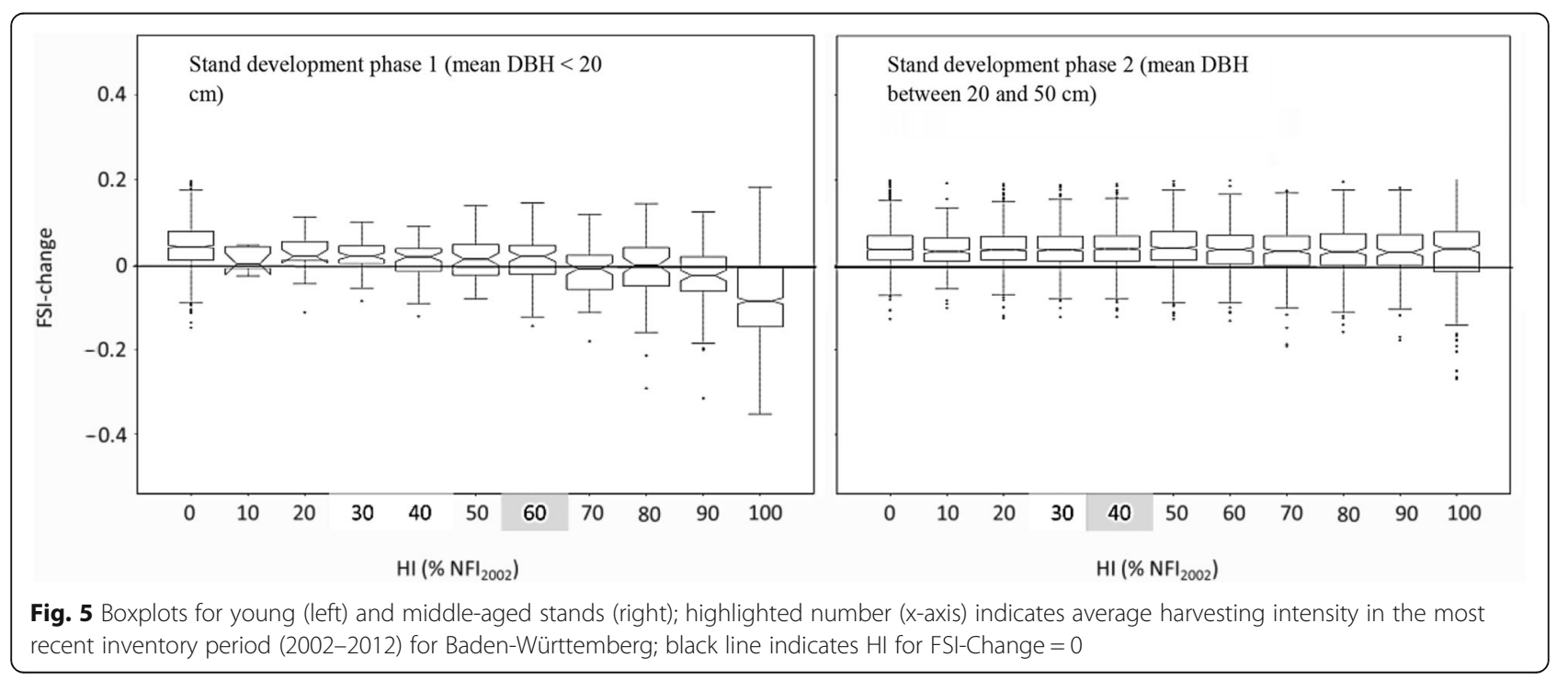




\section{Discussion}

Assessing changes in structural diversity based on NFI data Using the NFI-based index of structural diversity (FSI) (Storch et al. 2018), an assessment of the influence of previous harvesting intensities on forest structural diversity can be performed. Theoretically, this approach may be used to identify for different types of forests thresholds of harvesting intensity before a reduction in the overall structural diversity occurs. Our results show, that structural diversity, as it was quantified here, is not very sensitive to harvesting intensity. Hence, in a sustainable forest management framework, other indicators that are more directly linked to the sustained provision of ecosystem services would be considered more important for determining upper limits of harvesting intensity. At a local level, limits to harvesting intensities may be set by changes in more sensitive variables such as the volume of large trees, if they present habitats for rare and endangered species like species such as those depending on deadwood of large dimensions or large trees including habitat characteristics (Bütler and Schlaepfer 2004; Bußler et al. 2007).

One major outcome of our analysis is that harvesting does not automatically reduce the level of structural diversity. Especially harvesting intensities lower than 20\%$30 \%$ of the standing volume in $\mathrm{NFI}_{2002}$ have led to a slight increase or maintenance of structural diversity in most types of forest ecosystems (Additional file 1). This perhaps surprising observation may be explained by a number of points.

First, the index of structural diversity aims at a comprehensive cover of structural attributes that provide important habitat components of forest-dwelling species (Storch 2018; Penone et al. 2019). Unlike other indices (e.g. the 'Old-Growth Index' developed by Acker et al. (1998)) it is therefore not focussed on structural attributes of old forests, which are often in the focus of biodiversity conservation approaches. An index focussing on such old-growth attributes may be more sensitive to harvesting intensity.

Secondly, in our index, some aspects of structure clearly benefit from harvesting, e.g. tree species richness in the regeneration layer, which increases with additional light demanding species (Hooper et al. 2005; Bauhus et al. 2017b).

Third, we have only analysed the short-term changes (10 years) in forest structural diversity in relation to harvesting intensity. There may be contrasting patterns for short-term and long-term responses to certain harvesting-related impacts. For example, in the short term, harvesting may provide larger amounts of deadwood in the form of tree parts that are not removed than would be found in otherwise undisturbed forests (Meyer 1999). However, in the long run, more deadwood of larger dimension would accumulate in forests with little or no harvesting, where deadwood would be generated by natural disturbances (Christensen et al. 2005). While unharvested, primary forests may have a high degree of structural diversity (Stiers et al. 2018), it may also be high following natural disturbances (e.g. Nagel et al. 2006; Thom and Seidl 2016). For example, windstorms or fires create deadwood, increase light conditions near the ground that influence species richness in the regeneration layer and lead to establishment of pioneer tree species that increase tree species richness and the diversity of pollen and fruit production (Hooper et al. 2005; Bauhus et al. 2017b; Hilmers et al. 2018). However, many of the inventory plots without harvesting in the most recent inventory period do not represent strictly protected forest reserves, which might develop into structurally diverse stands in the long term, but merely patches that were excluded from harvesting for that period. In the state of Baden-Württemberg, the number of forest inventory plots where no trees were harvested amounted to $34 \%$ of the total number of plots. This contrasts with an area of strictly protected reserves of only $2.8 \%$ in the state for 2012. Therefore, many of the plots without harvesting in the most recent inventory period might have been harvested in the previous period (about $76 \%$ of unharvested plots for inventory period 20022012). In addition, in the majority of strictly protected forest reserves, which cover only a small proportion of Germany's total forest area (Engel et al. 2016), management has ceased only recently or a few decades ago and therefore there has been little time to develop high levels of structural diversity. Hence, we do not necessarily have high levels of those structural variables indicative of old and unharvested forests at zero or low levels of harvesting intensity. This also indicates that long-term monitoring is required to facilitate meaningful interpretation of the relationship between harvesting intensity and structural diversity. Any short-term changes to structural diversity from harvesting will be more pronounced in plots harvested recently before the last inventory, whereas they will be at least partly compensated in plots harvested in the beginning of the last inventory period (see also further below).

Fourth, new management strategies such as 'retention forestry' have been employed to reduce the influence of harvesting on biodiversity through the deliberate maintenance of important structural elements such as habitat trees and dead wood to sustain structural diversity of forests (Hartsough 2003; Gustafsson et al. 2012). However, as mentioned above, it is not clear to what extent these relatively recent changes have already influenced structural diversity in the last forest inventory.

The assessment of structural diversity in forests using data sampled by the angle count method contains a 
certain inaccuracy, which is caused by the selective sampling of trees $\geq 7 \mathrm{~cm}$ DBH (Storch et al. 2018). This can be seen in the changes in forest structural diversity that were recorded in individual inventory plots, where actually no harvesting took place (Fig. 5). Here, the changes in FSI at the plot level were partially the result of the applied sampling method (angle count sampling). For example, the highest increase in structural diversity for a single plot without recorded harvesting was 2186\% (FSI_ $\mathrm{NFI}_{2002}$ : 0.01, FSI_NFI $\mathrm{NF}_{2012}: 0.26$ ), which was caused by the sampling method and not by substantial changes in natural conditions. In this concrete case, the FSI score increased dramatically as a result of ingrowth of several trees into the collective of trees sampled by the angle count method.

This expected limitation at the plot-level is accounted for by aggregation to forest types using mean values of the developed index and the included structural variables to assess the level of structural diversity and the changes over inventory periods. In addition, the calculated HI can include an inaccuracy that is caused by extrapolating volumes of sampled trees to hectare-values, which is necessary when using angle-count sampling. In one extreme case, the calculated tree volume $\mathrm{ha}^{-1}$ at one inventory plot at the time of $\mathrm{NFI}_{2002}$ was 142 $\mathrm{m}^{3} \cdot \mathrm{ha}^{-1}$, while the harvested volume at this plot in the following inventory period was $258 \mathrm{~m}^{3} \cdot \mathrm{ha}^{-1}$, leading to a harvesting intensity of $181 \%$ although the volume ha ${ }^{-1}$ at the time of $\mathrm{NFI}_{2012}$ was $231 \mathrm{~m}^{3} \cdot \mathrm{ha}^{-1}$. The high standing volume of $\mathrm{NFI}_{2012}$ at this particular sampling point was attributable to seven newly sampled trees, which were not sampled at $\mathrm{NFI}_{2002}$. The addition of these trees was the result of tree selection by the angle count method, which is based on tree distance and diameter. This extreme example shows the inherent issue of angle count sampling that plot-level information is not representative of the forest stand. This further underlines the need for aggregation of inventory plots to strata.

Another reason for the low impacts of HI on structural diversity might be the variable time span between the time of harvesting and the second assessment of structural variables at the end of the inventory period. For example, harvesting could have taken place directly before the inventory sampling of $\mathrm{NFI}_{2012}$, and thus have an immediate impact on certain variables, or shortly after the previous sampling close to 10 years earlier. In the latter case, the impact of harvesting could have been partially compensated by processes such as tree growth or it may have only become apparent in the form of a more species rich tree regeneration layer. Variables such as 'quadratic mean diameter at breast height' and 'volume of trees with a diameter at breast height $\geq 40 \mathrm{~cm}$ ' could change immediately after harvesting, while variables such as the 'number of decay classes' and 'mean diameter of downed deadwood' might require years to decades to change in their expression. This uncertainty at the level of individual plots can however be overcome by aggregation to different types of forests, and thus increase the reliability of the results. This might partly explain the fact, that inventory plots with a $\mathrm{HI}$ of $100 \%$ can show a positive change of the FSI. In addition, one limitation of the sampling approach of the NFI and thus the FSI is that it does not account for spatial patterns of structural elements such as trees, although these can contribute considerably to structural diversity in forests (Schall et al. 2018b).

\section{Assessment of harvesting intensities for period $\mathrm{NFI}_{2002}-$ $\mathrm{NFI}_{2012}$ in different types of forests}

Our results show that HI could theoretically be increased without a loss in structural diversity for all analysed types of forests, except for young stands (SDP1). Additionally, harvesting intensity for most types of forests was below the annual increment level. Thus, a certain level of intensification would also not exceed the sustainable yield. Standing tree volume increased from 486 million $\mathrm{m}^{3}$ at $\mathrm{NFI}_{2002}\left(365 \mathrm{~m}^{3} \cdot \mathrm{ha}^{-1}\right)$ to 499 million $\mathrm{m}^{3}$ at $\mathrm{NFI}_{2012}\left(377 \mathrm{~m}^{3} \cdot \mathrm{ha}^{-1}\right)$ for Baden-Württemberg (Eltrop et al. 2006; Kändler and Cullmann 2014). Some forest types can theoretically be harvested more intensely than others before a loss in structural diversity sets in. As shown in Additional file 1, broadleaf-dominated forest stands have less potential in this regard than conifer-dominated stands. Structural diversity in beech (Fagus sylvatica L.) and oak-dominated (Quercus spp.) stands appeared to be more sensitive towards $\mathrm{HI}$ than spruce-dominated (Picea abies L.) stands (Additional file $1)$. These differences are mainly caused by different stand characteristics and therefore by different responses of individual variables to harvesting intensity. For example, the variables 'species richness in the regeneration layer' (caused by a higher species richness of the regeneration layer in broadleaf-dominated stands), 'diameter at breast height of standing deadwood', 'standard deviation of stand height' (caused by the fact that broadleafdominated stands are more often multi-layered stands and therefore show a higher expression of this variable as conifer-dominated stands, which are often one-layered stands) and 'diversity of bark types' all responded more sensitively to harvesting intensity. All other structural variables had more positive changes with increasing $\mathrm{HI}$ in broadleaf-dominated stands than in coniferousdominated stands (Additional file 4). Some individual structural variables seem to be not affected by harvesting at all (e.g. standing deadwood or flower diversity). One could argue that these variables should therefore be dropped from the index. Keeping insensitive variables in the index could blur the impact of harvesting on the FSI. 
That would be true for percent changes but not for absolute changes. However, a reduction of variables to the ones being sensitive to $\mathrm{HI}$ was not performed, because all included variables cover an important aspect of structural and taxonomic diversity and should be included in a comprehensive assessment of diversity, even if at this stage, no change was recorded over one inventory period.

Harvesting intensity was derived in our inventory-based study from the volume of trees that were removed. However, this variable does not indicate how much biomass was actually taken from the forest, since variable proportions of residues may remain in the forest. Woody material smaller than $10 \mathrm{~cm}$ diameter is not captured as dead wood in the inventory. Hence, the influence of harvesting forest residues smaller than $10 \mathrm{~cm}$ on structural diversity and biodiversity, which can be very important (e.g. Ranius et al. 2018) cannot be captured by our approach.

\section{Influence of harvests on individual structural variables}

Impacts of harvests on individual structural variables included in the Forest Structure Index are quite variable and should be assessed separately. For example, the amount of downed deadwood might increase after harvests, which favours the deadwood depending flora and fauna. As timber harvests produce mainly small-dimensioned deadwood such as in crowns left on site, especially taxonomic groups depending on these small diameters and early decay classes of deadwood will be supported, as e.g. Brin et al. (2011) showed for saproxylic beetle assemblages. Other saproxylic species relying on large dimension deadwood are likely disadvantaged in the long-term by increasing harvesting intensity, if no special provision is made (e.g. Lachat et al. 2013).

Species richness in the regeneration layer responded positively to harvesting, although there was no further increase beyond 20\% harvesting intensity. Obviously, given the high average growing stock in the forests, harvesting improves light conditions near the ground and thus facilitates regeneration and establishment of more light demanding species (Boch et al. 2013). This finding is in agreement with those of a recent study that showed that there is no positive effect of aboveground carbon stocks of European broadleaved forests on multi-taxa biodiversity (Sabatini et al. 2019). This study showed that in particular among plant species, more species are lost than gained with increasing aboveground carbon stocks; including those shade-intolerant and drought-tolerant species which may be required for adaptation of forests to climate change (Kunz et al. 2018).

Other variables like the occurrence of large trees with a diameter at breast height $\geq 40 \mathrm{~cm}$ will inevitably be reduced at high levels of harvesting intensity, so populations of species depending on these habitats (e.g. epiphytes) might also be reduced. An overview of all variables applied in the FSI and their changes with increasing harvesting intensity is provided in Additional file 4. Therefore, influences of harvests or harvesting intensity can have totally different impacts on single taxonomic groups or individual species within taxonomic groups. As has been shown by Sabatini et al. (2019) within the taxonomic groups of vascular plants, lichens, fungi, bryophytes, beetles, and birds found in oak and beech dominated forests, the majority of species are not influenced by aboveground biomass $C$ stocks, yet within each of these groups there are some winners and losers of increasing or decreasing stocks.

Regarding the beta- and gamma-diversity of forestdwelling species across different taxonomic groups, a mixture of patches with high and low FSI-values at the landscape-level may be recommended, as is suggested by the analysis of Schall et al. (2018a) for a beech forest landscape in the German Biodiversity Exploratories. Leston et al. (2018) showed that long-term changes of structural elements of forests after different harvesting approaches can provide habitats for different bird species and thus increase the overall species richness when compared to unharvested stands. Therefore, to maintain high-levels of species diversity, a broad spectrum of structural elements and structural diversity should be present at the landscape-level (Okland 1996; Sullivan and Sullivan 2001; Schall et al. 2018a).

The main focus of this study was on the influence of harvesting intensity on forest structural diversity, whereas harvesting methods were not considered because there is no relevant information available in the NFI-data of Germany. Different harvesting methods such as selection cutting (e.g. single tree or group selection) lead to differences in structural diversity of forests too (Siira-Pietikäinen et al. 2001; Rosenvald and Lohmus 2008; Kuuluvainen 2009). Retention forestry can support structural diversity by maintaining certain structural elements or creating them artificially (e.g. standing dead trees or high stumps; Abrahamsson and Lindbladh 2006; Bauhus et al. 2009; Gustafsson et al. 2012). It would be very valuable, if inventories provided information about the influences of different harvesting and regeneration methods on forest structural diversity since this information could be used to evaluate these management systems on a large scale.

\section{Conclusion}

Our results show the general possibility to use largescale inventory data like the NFI of Germany to analyse the influence of harvesting intensity on structural diversity of different forest stands. The small influence of harvesting intensity on forest structural diversity and individual structural variables over a period of 10 years 
was surprising. At the scale of forest types or the entire forest area, the results suggest that harvesting as practiced in the forests of south-western Germany has no negative impact on structural diversity and thus the diversity of habitats. However, at very high harvesting intensities of greater than $70 \%$ of the growing stock, structural diversity can be impaired. The monitoring of the influence of harvesting intensity on structural diversity should be continued, considering the medium-to longterm influence, which may be different from short-term responses. The observed trends in the development of aspects of forest structural elements may help to understand changes in the occurrence and abundance of forest-dwelling species.

\section{Additional files}

Additional file 1: Boxplots for analysed types of forests in SW-Germany illustrating the influences of harvesting intensities (10\%-intervals of standing volume at $\mathrm{NFI}_{2002}, x$-axis) on changes in structural diversity of forests (FSI-Change, $y$-axis). Black line indicates no change in structural diversity; highlighted number ( $x$-axis) indicates mean harvesting intensity of period 2002-2012. (PDF $490 \mathrm{~kb}$ )

Additional file 2: Changes of individual variable ranges ('variablerange_NFI 2012 ' - 'variable-range_NFI ${ }_{2002}$ ') with increasing $\mathrm{HI}$ (HI-classes of $10 \%$ referred to $\mathrm{NF}_{2002}$-value) for forests of whole Baden-Württemberg; mean harvesting intensity of 31\% (box ' 40 '). (PDF $419 \mathrm{~kb}$ )

Additional file 3: Changes of individual variables applied in the FSI (yaxis: change of variable ranges; $x$-axis: classes for $\mathrm{HI}$ of $10 \%$-intervals (0$100 \%$ ), referred to standing volume at $\mathrm{NF}_{2002}$ ), for all analysed types of forests. (PDF $1349 \mathrm{~kb}$ )

Additional file 4: Changes of applied variables in the FSI with increasing $\mathrm{HI}$ for all analysed forest types; $x$-axis: increasing $\mathrm{HI}$ in $10 \%$ intervals of $\mathrm{NF}_{2002}$ standing volume; $y$-axis: change of variable range. (PDF $1249 \mathrm{~kb})$

\section{Abbreviations}

BL: Broadleaf-dominated forest stand; BW: State of Baden-Württemberg, SWGermany; CF: Conifer-dominated forest stand; DBH: Diameter at breast height $(130 \mathrm{~cm})$; DBHq: Quadratic diameter at breast height $(130 \mathrm{~cm})$; FORMI: Forest management index; FSI: Forest Structure Index; HI: Harvesting intensity; $\mathrm{m}^{3} \cdot \mathrm{ha}^{-1}$ : Cubic metre per hectare; $\mathrm{NFI}_{2002}$ / 2012: German National Forest Inventory of 2002 and 2012; SDP: Stand development phase; SDP1: mean $\mathrm{DBH}<20 \mathrm{~cm}$ (taken from NFI classification); SDP2: mean DBH between 20 and $50 \mathrm{~cm}$ (taken from NFI classification); SDP3: mean DBH > 50 $\mathrm{cm}$ (taken from NFI classification); SW: South-west Germany; Vol40: Volume $\mathrm{ha}^{-1}$ of trees with a DBH $\geq 40 \mathrm{~cm}$

\section{Acknowledgements}

Not applicable.

\section{Authors' contributions}

FS planned and conducted the study including data management and analysis and wrote the majority of the manuscript; GK provided support in inventory analysis and contributed to the manuscript; JB conceived and guided the study and co-wrote the manuscript.

\section{Authors' information}

Not applicable.

\section{Funding}

This work was supported by a grant from the Ministry of Science, Research and the Arts of Baden-Württemberg (7533-10-5-78) to Jürgen Bauhus. Felix
Storch received additional support through the BBW ForWerts Graduate Program.

\section{Availability of data and materials}

The datasets that form the basis of all analyses in our study are free available at https://bwi.info/Download/de/BWI-Basisdaten/ACCESS2003/.

The datasets supporting the conclusions of this article are included in the additional files 1-4.

Ethics approval and consent to participate

Not applicable.

\section{Consent for publication}

Not applicable.

\section{Competing interests}

The authors declare that they have no competing interests.

\section{Author details}

${ }^{1}$ Chair of Silviculture, University of Freiburg, D-79085 Freiburg, Germany.

2Department of Biometry, Forest Research Institute of Baden-Württemberg, D-79100 Freiburg, Germany.

Received: 17 April 2019 Accepted: 19 August 2019

Published online: 17 September 2019

\section{References}

Abrahamsson M, Lindbladh M (2006) A comparison of saproxylic beetle occurrence between man-made high- and low-stumps of spruce (Picea abies). For Ecol Manag 226(1-3):230-237. https://doi.org/10.1016/j.foreco.2 006.01 .046

Acker SA, Sabin TE, Ganio LM, McKee WA (1998) Development of old-growth structure and timber volume growth trends in maturing Douglas-fir stands. For Ecol Manag 104(1-3):265-280. https://doi.org/10.1016/S0378-112 7(97)00249-1

Bartha D (2004) Die Naturnähe der Wälder - Bewertung auf Bestandesebene. Allg Forst-und Jagdzeitung 175:8-12

Bauhus J, Forrester DI, Gardiner B, Jactel H, Vallejo R, Pretzsch H (2017b) Ecological stability of mixed-species forests. In: Pretzsch $\mathrm{H}$, Forrester $\mathrm{D}$, Bauhus J (eds) Mixed-species forests - ecology and management. Springer, Berlin Heidelberg, pp 337-382

Bauhus J, Kouki J, Paillet Y, Asbeck T, Marchetti M (2017a) How does the forestbased bioeconomy impact forest biodiversity? In: Winkel G (ed) Towards a sustainable European forest-based bioeconomy - assessment and the way forward. What science can tell us 8, European Forest Institute, pp 67-76

Bauhus J, Puettmann K, Messier C (2009) Silviculture for old-growth attributes. For Ecol Manag 258(4):525-537. https://doi.org/10.1016/j.foreco.2009.01.053

Bitterlich W (1952) Die Winkelzählprobe. Forstwiss Centralblatt 71(7):215-225

BMEL (2013) The National Forest Inventory. Available at BMEL. https://www. bundeswaldinventur.de. Accessed 10 July 2019

Boch S, Prati D, Müller J, Socher S, Baumbach H, Buscot F, Gockel S, Hemp A, Hessenmöller D, Kalko EKV, Linsenmair KE, Pfeiffer S, Schöning I, Schulze ED, Seilwinder C, Weisser WW, Wells K, Fischer M (2013) High plant species richness indicates management-related disturbances rather than the conservation status of forests. Basic Appl Ecol 14(6):496-505. https://doi.org/1 0.1016/j.baae.2013.06.001

Brin A, Bouget C, Brustel H, Jactel H (2011) Diameter of downed woody debris does matter for saproxylic beetle assemblages in temperate oak and pine forests. J Insect Conserv 15(5):653-669. https://doi.org/10.1007/s10841-0109364-5

Bußler H, Blaschke M, Dorka V, Loy H, Strätz C (2007) Auswirkungen des Rothenbucher Totholz-und Biotopbaumkonzepts auf die Struktur-und Artenvielfalt in Rot-Buchenwäldern. Waldökologie Online 4:5-58

Bütler R, Schlaepfer R (2004) Wie viel Totholz braucht der Wald? Dead wood in managed forests: how much is enough? Schweiz Zeitschr Forstwesen 155(2): 31-37. https://doi.org/10.3188/szf.2004.0031

Cazzolla Gatti R, Castaldi S, Lindsell JA, Coomes DA, Marchetti M, Maesano M et al (2015) The impact of selective logging and clearcutting on forest structure, tree diversity and above-ground biomass of African tropical forests. Ecol Res 30(1):119-132 1007/s11284-014-1217-3 
Christensen M, Hahn K, Mountford EP, Odor P, Standovár T, Rozenbergar D, Diaci J, Wijdeven S, Meyer P, Winter S, Vrska T (2005) Dead wood in European beech (Fagus sylvatica) forest reserves. For Ecol Manag 210(1-3):267-282. https://doi.org/10.1016/j.foreco.2005.02.032

de Avila AL, Ruschel AR, Olegário Pereira de Carvalho J, Mazzei L, JNM S, do Carmo Lopes J, Machado Araujo M, Dormann CF, Bauhus J (2015) Mediumterm dynamics of tree species composition in response to silvicultural intervention intensities in a tropical rain forest. Biol Conserv 191:577-586. https://doi.org/10.1016/j.biocon.2015.08.004

Eltrop L, Moerschner J, Härdtlein M, König A (2006) Bilanz und Perspektiven der Holzenergienutzung in Baden-Württemberg. Available at Univ Stuttgart https://elib.uni-stuttgart.de/handle/11682/1708. Accessed 11 July 2019. https://doi.org/10.18419/opus-1691

Engel F, Bauhus J, Gärtner S, Kühn A, Meyer P, Reif A, Schmidt M, Schultze J, Späth V, Stübner S, Wildmann S, Spellmann H (2016) Wälder mit natürlicher Entwicklung in Deutschland: Bilanzierung und Bewertung. Naturschutz und Biologische Vielfalt 145. Bundesamt für Naturschutz, Bonn, p 274

Franklin JF, Spies TA, Van Pelt R, Carey AB, Thornburgh DA, Berg DR, Lindenmayer DB, Harmon ME, Keeton WS, Shaw DC, Bible K, Chen J (2002) Disturbances and structural development of natural forest ecosystems with silvicultural implications, using Douglas-fir forests as an example. For Ecol Manag 155: 399-423. https://doi.org/10.1016/S0378-1127(01)00575-8

Fredericksen TS, Ross BD, Hoffman W, Morrison ML, Beyea J, Bradley NJ, Lester MB, Ross E (1999) Short-term understory plant community responses to timber-harvesting intensity on non-industrial private forestlands in Pennsylvania. For Ecol Manag 116(1-3):129-139. https://doi.org/10.1016/S03 78-1127(98)00452-6

Gilliam FS (2002) Effects of harvesting on herbaceous layer diversity of a central Appalachian hardwood forest in West Virginia, USA. For Ecol Manag 155(13):33-43. https://doi.org/10.1016/S0378-1127(01)00545-X

Glaser F (2006) Biogeography, diversity, and vertical distribution of ants (Hymenoptera: Formicidae) in Vorarlberg, Austria. Myrmecologische Nachrichten 8:263-270

González-Alday J, Martínez-Ruiz C, Bravo F (2008) Evaluating different harvest intensities over understory plant diversity and pine seedlings, in a Pinus pinaster Ait. Natural stand of Spain. In: Van der Falk AG (ed) For Ecol. Springer, Dordrecht, pp 211-220. https://doi.org/10.1007/s11258-008-9490-2

Gossner MM, Lachat T, Brunet J, Isacsson G, Bouget C, Brustel H et al (2013) Current near-to-nature forest management effects on functional trait composition of saproxylic beetles in beech forests. Conserv Biol 27(3):605614. https://doi.org/10.1111/cobi.12023

Gustafsson L, Baker SC, Bauhus J, Beese WJ, Brodie A, Kouki J, Neyland M (2012) Retention forestry to maintain multifunctional forests: a world perspective. BioScience 62(7):633-645. https://doi.org/10.1525/bio.2012.62.7.6

Hartsough B (2003) Economics of harvesting to maintain high structural diversity and resulting damage to residual trees. Western J Appl For 18(2):133-142. https://doi.org/10.1093/wjaf/18.2.133

Hilmers T, Friess N, Bässler C, Heurich M, Brandl R, Pretzsch H, Seidl R, Müller J (2018) Biodiversity along temperate forest succession. J Appl Ecol 55(6):27562766. https://doi.org/10.1111/1365-2664.13238

Hooper DU, Chapin FS, Ewel JJ, Hector A, Inchausti P, Lavorel S, Lawton JH, Lodge DM, Loreau M, Naeem S, Schmid B, Setälä H, Symstad AJ, Vandermeer J, Wardle DA (2005) Effects of biodiversity on ecosystem functioning. A consensus of current knowledge. Ecol Monogr 75(1):3-35. https://doi.org/1 0.1890/04-0922

Jung K, Kaiser S, Böhm S, Nieschulze J, Kalko EKV (2012) Moving in three dimensions. Effects of structural complexity on occurrence and activity of insectivorous bats in managed forest stands. J Appl Ecol 49(2):523-531. https://doi.org/10.1111/j.1365-2664.2012.02116.x

Kahl T, Bauhus J (2014) An index of forest management intensity based on assessment of harvested tree volume, tree species composition and dead wood origin. Nature Conserv 7:15-27. https://doi.org/10.3897/ natureconservation.7.7281

Kändler G, Cullmann D (2014) Der Wald in Baden-Württemberg. Ausgewählte Ergebnisse der dritten Bundeswaldinventur Available at ForstBW. http:// forstbw.de/schuetzen-bewahren/waldinventur/bundeswaldinventur/bwi3. html. Accessed 6 July 2019

Kern CC, Palik BJ, Strong TF (2006) Ground-layer plant community responses to even-age and uneven-age silvicultural treatments in Wisconsin northern hardwood forests. For Ecol Manag 230(1-3):162-170. https://doi.org/10.1016/ j.foreco.2006.03.034
Kunz J, Löffler G, Bauhus J (2018) Minor European broadleaved tree species are more drought-tolerant than Fagus sylvatica but not more tolerant than Quercus petraea. For Ecol Manag 414:15-27. https://doi.org/10.1016/j.foreco.2 018.02.016

Kuuluvainen T (2009) Forest management and biodiversity conservation based on natural ecosystem dynamics in northern Europe. The complexity challenge. AMBIO 38(6):309-315. https://doi.org/10.1579/08-A-490.1

Lachat T, Bouget C, Bütler R, Müller J (2013) Deadwood: quantitative and qualitative requirements for the conservation of saproxylic biodiversity. In: Kraus D, Krumm F (eds) Integrative approaches as an opportunity for the conservation of forest biodiversity. European Forest Institute, Joensuu, pp 92-102

Laiolo P (2002) Effects of habitat structure, floral composition and diversity on a forest bird community in North-Western Italy. Folia Zool 51(2):121-128

Leston L, Bayne E, Schmiegelow F (2018) Long-term changes in boreal forest occupancy within regenerating harvest units. For Ecol Manag 421:40-53. https://doi.org/10.1016/j.foreco.2018.02.029

Lindenmayer DB, Margules CR, Botkin DB (2000) Indicators of biodiversity for ecologically sustainable Forest management. Conserv Biol 14(4):941-950. https://doi.org/10.1046/j.1523-1739.2000.98533.x

McDermott C, Cashore BW, Kanowski P (2010) Global environmental forest policies: an international comparison. Earthscan, London, p 393

McElhinny C, Gibbons P, Brack C (2006b) An objective and quantitative methodology for constructing an index of stand structural complexity. For Ecol Manag 235(1-3):54-71. https://doi.org/10.1016/j.foreco.2006.07.024

McElhinny C, Gibbons P, Brack C, Bauhus J (2006a) Fauna-habitat relationships: a basis for identifying key stand structural attributes in temperate Australian eucalypt forests and woodlands. Pac Conserv Biol 12:89-110. https://doi. org/10.1071/PC060089

Meyer P (1999) Totholzuntersuchungen in nordwestdeutschen Naturwäldern. Methodik und erste Ergebnisse. Forstwiss Centralblatt 118(1-6):167-180. https://doi.org/10.1007/BF02768985

Michel AK, Winter S (2009) Tree microhabitat structures as indicators of biodiversity in Douglas-fir forests of different stand ages and management histories in the Pacific northwest, U.S.a. For Ecol Manag 257(6):1453-1464. https://doi.org/10.1016/j.foreco.2008.11.027

Motz K, Sterba H, Pommerening A (2010) Sampling measures of tree diversity. For Ecol Manag 260(11):1985-1996. https://doi.org/10.1016/j. foreco.2010.08.046

Müller J, Bußler H, Kneib T (2008) Saproxylic beetle assemblages related to silvicultural management intensity and stand structures in a beech forest in southern Germany. J Insect Conserv 12:107. https://doi.org/10.1007/s10841006-9065-2

Nagel TA, Svoboda M, Diaci J (2006) Regeneration patterns after intermediate wind disturbance in an old-growth Fagus-Abies forest in southeastern Slovenia. For Ecol Manag 226(1-3):268-278. https://doi.org/10.1016/j.foreco.2 006.01 .039

Neuner S, Albrecht A, Cullmann D, Engels F, Griess VC, Hahn WA, Hanewinkel M, Härtl F, Kölling C, Staupendahl K, Knoke T (2015) Survival of Norway spruce remains higher in mixed stands under a dryer and warmer climate. Glob Chang Biol 21(2):935-946. https://doi.org/10.1111/gcb.12751

Okland B (1996) Unlogged forests: important sites for preserving the diversity of mycetophilids (Diptera: Sciaroidea). Biol Conserv 76:297-310. https://doi.org/1 0.1016/0006-3207(95)00129-8

Okland TK, Rydgren RH, Økland K, Storaunet O, Rolstad J (2003) Variation in environmental conditions, understorey species number, abundance and composition among natural and managed Picea-abies forest stands. For Ecol Manag 177:17-37. https://doi.org/10.1016/S0378-1127(02)00331-6

Paillet $Y$, Bergès L, Hiältén J, Ódor P, Avon C, Bernhardt-Römermann M, Bijlsma RJ, de Bruyn L, Fuhr M, Grandin U, Kanka R, Lundin L, Luque S, Magura T, Matesanz $S$, Mèszàros I, Sebastià MT, Schmidt W, Standovàr T, Tòthmeresz B, Uotila A, Valladares F, Vellak K, Virtanen R (2010) Biodiversity differences between managed and unmanaged forests: meta-analysis of species richness in Europe. Conserv Biol 24(1):101-112. https://doi.org/10.1111/j.1523-1739.2 009.01399.x

Parrotta JA, Francis JK, Knowles OH (2002) Harvesting intensity affects forest structure and composition in an upland Amazonian forest. For Ecol Manag 169(3):243-255. https://doi.org/10.1016/S0378-1127(01)00758-7

Penone C, Allan E, Soliveres S, Felipe-Lucia MR, Gossner MM, Seibold S, Simons NK, Schall P, van der Plas F, Manning P, Manzanedo RD, Boch S, Prati D, Ammer C, Bauhus J, Buscot F, Ehbrecht M, Goldmann K, Jung K, Müller J, 
Müller JC, Pena R, Polle A, Renner SC, Ruess L, Schönig I, Schrumpf M, Solly EF, Tschapka M, Weisser WW, Wubet T, Fischer M (2019) Specialisation and diversity of multiple trophic groups are promoted by different forest features. Ecol Lett 22(1):170-180. https://doi.org/10.1111/ele.13182

Puettmann KJ, SMcG W, Baker S, Donoso P, Droessler L, Amente G, Harvey BD, Knoke T, Lu Y, No-centini S, Putz FE, Yoshida T, Bauhus J (2015) Silvicultural alternatives to conventional even-aged forest management - what limits global adoption? For Ecosyst 2:8. https://doi.org/10.1186/s40663-015-0031-x

Raison RJ, Flinn DW, Brown AG (2001) Application of criteria and indicators to support sustainable forest management: some key issues. In: Raison RJ, Flinn DW, Brown AG (eds) Criteria and indicators for sustainable Forest management. CAB International, Wallingford, pp 5-18

Ranius T, Hämäläinen A, Egnell G, Olsson B, Eklöf K, Stendahl J et al (2018) The effects of logging residue extraction for energy on ecosystem services and biodiversity: a synthesis. J Environ Manag 209:409-425. https://doi.org/10.1 016/j.jenvman.2017.12.048

Roberts MR, Zhu L (2002) Early response of the herbaceous layer to harvesting in a mixed coniferous-deciduous forest in New Brunswick, Canada. For Ecol Manag 155(1-3):17-31. https://doi.org/10.1016/S0378-1127(01)00544-8

Rosenvald R, Lohmus A (2008) For what, when, and where is green-tree retention better than clear-cutting? A review of the biodiversity aspects. For Ecol Manag 255(1):1-15. https://doi.org/10.1016/j.foreco.2007.09.016

Sabatini FM, Burrascano S, Lombardi F, Chirici G, Blasi C (2015) An index of structural complexity for Apennine beech forests. iForest 8(3):314-323. https://doi.org/10.3832/ifor1160-008

Sabatini FM, de Andrade RB, Paillet Y, Ódor P, Bouget C, Campagnaro T, Gosselin F, Janssen P, Mattioli W, Nascimbene J, Sitzia T, Kuemmerle T, Burrascano S (2019) Trade-offs between carbon stocks and biodiversity in European temperate forests. Glob Chang Biol 25(2):536-548. https://doi.org/10.1111/gcb.14503

Schall P, Ammer C (2013) How to quantify forest management intensity in central European forests. Eur J For Res 132(2):379-396. https://doi.org/10.1 007/s10342-013-0681-6

Schall P, Gossner MM, Heinrichs S, Fischer M, Boch S, Prati D, Jung K, Baumgartner V, Blaser S, Böhm S, Buscot F, Daniel R, Goldmann K, Kaiser K, Kahl T, Lange M, Müller J, Overmann J, Renner SC, Schulze ED, Sikorski J, Tschapka M, Türke M, Weisser WW, Wemheuer B, Wubet T, Ammer C (2018a) The impact of even-aged and uneven-aged forest management on regional biodiversity of multiple taxa in European beech forests. J Appl Ecol 55(1): 267-278. https://doi.org/10.1111/1365-2664.12950

Schall P, Schulze ED, Fischer M, Ayasse M, Ammer C (2018b) Relations between forest management, stand structure and productivity across different types of central European forests. Basic Appl Ecol 32:39-52. https://doi.org/10.1016/ j.baae.2018.02.007

Siira-Pietikäinen A, Pietikäinen J, Fritze H, Haimi J (2001) Short-term responses of soil decomposer communities to forest management: clear felling versus alternative forest harvesting methods. Can J For Res 31(1):88-99. https://doi. org/10.1139/x00-148

Simpson EH (1949) Measurement of diversity. Nature 163:688

Stiers M, Willim K, Seidel D, Ehbrecht M, Kabal M, Ammer C, Annighöfer P (2018) A quantitative comparison of the structural complexity of managed, lately unmanaged and primary European beech (Fagus sylvatica L.) forests. For Ecol Manag 430:357-365. https://doi.org/10.1016/j.foreco.2018.08.039

Storch F (2018) Influence of harvesting intensity on species and structura diversity of forests. Dissertation, University of Freiburg. https://doi.org/10.6 094/UNIFR/16801

Storch F, Dormann CF, Bauhus J (2018) Quantifying forest structural diversity based on large-scale inventory data: a new approach to support biodiversity monitoring. For Ecosyst 5(1):34. https://doi.org/10.1186/s40663-018-0151-1

Sullivan TP, Sullivan DS (2001) Influence of variable retention harvests on forest ecosystems. II Diversity and population dynamics of small mammals J Appl Ecol 38:1234-1252. doi:https://doi.org/10.1046/j.0021-8901.2001.00674.x

Sullivan TP, Sullivan DS, Lindgren PM (2008) Influence of variable retention harvests on forest ecosystems: plant and mammal responses up to 8 years post-harvest. For Ecol Manag 254(2):239-254. https://doi.org/10.1016/j. foreco.2007.08.005

Tews J, Brose U, Grimm V, Tielbörger K, Wichmann MC, Schwager M, Jeltsch F (2004) Animal species diversity driven by habitat heterogeneity/diversity. The importance of keystone structures. J Biogeogr 31(1):79-92. https://doi.org/1 0.1046/j.0305-0270.2003.00994.x
Thom D, Seidl R (2016) Natural disturbance impacts on ecosystem services and biodiversity in temperate and boreal forests. Biol Rev 91(3):760-781. https:// doi.org/10.1111/brv.12193

Thurm EA, Uhl E, Pretzsch H (2016) Mixture reduces climate sensitivity of Douglas-fir stem growth. For Ecol Manag 376:205-220. https://doi.org/10.1 016/j.foreco.2016.06.020

Urli M, Thiffault N, Barrette M, Belanger L, Leduc A, Chalifour D (2017) Key ecosystem attributes and productivity of boreal stands 20 years after the onset of silviculture scenarios of increasing intensity. For Ecol Manag 389: 404-416. https://doi.org/10.1016/j.foreco.2017.01.007

Vandekerkhove K, Thomaes A, Crèvecoeur L, de Keersmaeker L, Leyman A, Köhler F (2016) Saproxylic beetles in non-intervention and coppice-with-standards restoration management in Meerdaal forest (Belgium). An exploratory analysis iForest 9(4):536-545. https://doi.org/10.3832/ifor1841-009

Winter S, Fischer HS, Fischer A (2010) Relative quantitative reference approach for naturalness assessments of forests. For Ecol Manag 259(8):1624-1632. https:// doi.org/10.1016/j.foreco.2010.01.040

Wood SN (2006) Generalized additive models. An introduction with R Boca Raton: Chapman \& Hall/CRC (Texts in Statistical Science) doi:https://doi.org/1 $0.1201 / 9781315370279$

\section{Submit your manuscript to a SpringerOpen ${ }^{\circ}$ journal and benefit from:}

- Convenient online submission

- Rigorous peer review

- Open access: articles freely available online

- High visibility within the field

- Retaining the copyright to your article

Submit your next manuscript at $\boldsymbol{\sim}$ springeropen.com 